\title{
Metode Dakwah Islam, Katolik dan Penghayat di Kelurahan Cigugur Kabupaten Kuningan
}

\author{
Fahmi Alamsyah ${ }^{1}$, Dadan Suherdiana $^{1}$, Bahrudin $^{2}$ \\ ${ }^{1}$ Jurusan Komunikasi dan Penyiaran Islam, Fakultas Dakwah dan Komunikasi, \\ UIN Sunan Gunung Djati, Bandung \\ 2Jurusan Pengembangan Masyarakat Islam, Fakultas Dakwah dan Komunikasi, \\ UIN Sunan Gunung Djati, Bandung \\ *Email:fahmibmi19@gmail.com
}

\begin{abstract}
This study aims to determine the method of Islamic da'wah, Catholic and Penghayat located in Cigugur Kuningan District. The theory used in this research is SWOT analysis theory and the comparison theory of da'wah to find the pros and cons of da'wah done in Cigugur District. The method of this research is qualitative method, in which researcher about the method of da'wah of the object studied. Technique of collecting data in this research is literature study, document study and interview. From the research results can be concluded that every teaching that lives in Cigugur have dynamics respectively. Even when viewed from the method and its system, the method of propagating the religion of Catholic is superior to other religions although the number is still lost by Islam. However, it can be understood also that in reality the believer has no special purpose of getting people into their beliefs. In fact, every year the believer continues to berkurng and adhere to the religion that call it "recognized" by the state.
\end{abstract}

Keywords: method; Cigugur Kuningan; comparison da'wah

\begin{abstract}
ABSTRAK
Penelitian ini bertujuan untuk mengetahui metode dakwah Islam, Khatolik dan Penghayat yang berada di Kelurahan Cigugur Kabupaten Kuningan. Teori yang digunakan dalam penelitian ini adalah analisis SWOT dan teori perbandingan dakwah untuk menemukan kelebihan dan kekurangan dakwah di Kelurahan Cigugur. Metode penelitian ini adalah metode kualitatif, peneliti menulusuri mengenai metode dakwah dari objek yang diteliti. Teknik pengumpulan data dalam penelitian ini adalah studi kepustakaan, studi dokumen dan wawancara. Dari hasil penelitian dapat disimpulkan bahwa setiap ajaran yang hidup di cigugur memiliki dinamikanya masing-masing. Bahkan jika dilihat dari metode dan sistemnya, metode penyebaran agama Khatolik lebih unggul dari agama lainnya meskipun secara jumlah masih kalah oleh Islam. Akan tetapi, dapat dipahami juga bahwa ternyata penghayat tidak memiliki tujuan khusus mengajak orang-orang masuk kedalam kepercayaannya. Bahkan, setiap tahunnya penganut penghayat ini terus berkurng dan menganut pada agama yang sebut saja "diakui" oleh negara.
\end{abstract}


F. Alamsyah1, D. Suherdiana, \& Bahrudin

Kata Kunci : metode; Cigugur Kuningan; dakwah; perbandingan

\section{PENDAHULUAN}

Dakwah bukan hanya menyampaikan saja, namun harus memenuhi beberapa syarat diantaranya mencari materi yang cocok, mengetahui psikologis objek dakwah secara tepat, memilih metode yang representatif dan menggunakan bahasa yang bijaksana dan sebagainya.Semua aspek diatas akan menjadi stressing point pembahasan dalam metode dakwah (Suparta, 2009 : 5-6).

Dakwah ditinjau dari bahasa berarti panggilan, seruan atau ajakan bentuk perkataan tersebut dalam bahasa Arab disebut Mashdar.Sedangkan bentuk kerja atau fi'ilnya adalah da'a yad'u da'watan yang berarti memanggil, menyeru atau mengajak. Dari segi istilah, dakwah merupakan misi suci untuk mengajak manusia kejalan Allah hingga berubah hidupnya kearah yang lebih baik dengan menggunakan berbagai metode dan media (Muhyiddin, 2002 : 27).

Kegiatan dakwah telah berlangsung seumur sejarah peradaban manusia.Sederhananya dakwah adalah usaha yang dilakukan untuk mengajak seseorang keajaran Allah SWT.Karena dakwah dilakukan sejak Nabi Adam A.S diciptakan sampai kepada ummat Nabi Muhammad SAW hingga kepada manusia saat ini maka kita harus menengok kepada sejarah bagaimana keberhasilan metode dakwah para pendahulu.Dakwah merupakan suatu proses penyampaian pesanpesan tertentu yang berupa ajakan atau seruan dengan tujuan agar orang-orang memenuhi ajakan tersebut (Tasmara, 1997: 31).

Dakwah merupakan salah satu bentuk gerakan yang didukung ideologi tertentu untuk mencapai tujuan. Dakwah disamping sebagai ajaran agama, sejatinya adalah suatu aktivitas sosial yang bertujuan untuk mendorong orang lain dan masyarakat menuju pada perubahan yang lebih baik. Untuk mencapai itu, diperlukan organisasi dakwah, strategi, taktik dan mobilisasi massa dalam melakukan gerakan dakwah. (Rokhmad, 2010: 75).

Dari segi bahasa metode berasal dari dua kata yaitu "meta" (melalui) dan "hodos" (jalan atau cara) dengan demikian metode ialah cara atau jalan yang harus dilalui untuk mencapai suatu tujuan. Dalam bahasa Jerman methodica, artinyaajaran tentang metode. Dalam bahasa Yunani metode berasal dari kata methodos artinya jalan yang dalam bahasa arab disebut thariq. Dalam pengertian diatas dapat disimpulkan bahwa metode adalah jalan atau cara yang telah diatur (Suparta, 2006 :6).

Thariqatau thariqah identik dengan kata Ushlub.Ushlub secara bahasa adalah jalan atau seni sedangkat ushlub secara istilah menurut Syaikh al Jurjani adalah sesuatu yang dapat mengantarkan kepada tercapainya tujuan dengan paradigma yang benar. Kemudian menurut Bashrah Lubis Metode adalah "a sistematic arragement of things of ideas" yang artinya suatu sistem atau cara untuk menyusun atau mengatur suatu idea atau keinginan (AS, 2009 : 83).

Sedangkan dalam kamus besar bahaha Indonesia kata metode mengandung 
arti cara teratur yang digunakan untuk melaksanakan suatu pekerjaan agar tercapainya sesuai dengan yang dikehendaki, cara kerja yang bersistem untuk memudahkan pelaksanan suatu kegiatan guna mencapai tujuan yang di tentukan (Alya, 2009 :468).

Untuk menunjang tercapainya target yang diinginkan dalam penyajian materi-materi dakwah, masih menurut Quraish Shihab (1998), al-Qur'an menempuh beberapa metode, yaitu:

Pertama, mengemukakan kisah-kisah yang bertalian dengan salah satu tujuan materi. Kisah-kisah dalam al-Qur'an berkisar pada peristiwa-peristiwa sejarah yang terjadi dengan menyebut pelakupelaku dan tempat terjadinya (seperti kisah nabinabi), peristiwa yang telah terjadi dan masih dapat berulang kejadiannya, atau kisah simbolik yang tidak menggambarkan suatu peristiwa yang telah terjadi, namun dapat saja terjadi sewaktu-waktu.

Kedua, nasihat dan panutan. Al-Qur'an juga menggunakan kalimat-kalimat yang menyentuh hati untuk mengarahkan manusia kepada ide-ide yang dikehendakinya seperti terdapat dalam QS. 31:13-19. Tetapi nasihat yang dikemukakannya itu tidak banyak manfaatnya jika tidak dibarengi dengan contoh teladan dari pemberi atau penyampai nasihat, dalam hal pribadi Rasulullah. Pada diri beliau telah terkumpul segala macam keistimewaan, sehingga orang-orang yang mendengar ajaran-ajaran al-Qur'an melihat penjelmaan ajaran tersebut dalam dirinya, yang pada akhirnya mendorong mereka untuk meyakini keistimewaan dan mencontoh pelaksanaannya.

Ketiga, pembiasaan. Pembiasaan mempunyai peranan yang sangat besar dalam kehidupan manusia, karena dengan pembiasaan seseorang dapat melakukan hal-hal yang penting dan berguna tanpa menggunakan energi dan waktu yang banyak, dari sini dijumpai al-Qur'an"pembiasaan" sebagai proses mencapai target yang diinginkannya dalam penyajian materi. Pembiasaan tersebut menyangkut segi-segi pasif (meninggalkan sesuatu) atau pun aktif (melaksanakan sesuatu) (Aliyudin, 2010: 1013-1014).

Prinsip metode dakwah artinya ruh atau sifat yang menyemangati atau melandasi berbagai cara atau pendekatan dalam kegiatan dakwah. Untuk lebih jelas diantaranya mengacu kepada petunjuk al-Quran surat al-Nahl ayat 125 terdiri dari tiga prinsip yaitu al-hikmah, al-mauidzah al-hasanah, dan mujadalah bi al-lati hiya ahsan.

"Serulah manusia kepada jalan Tuhanmu dengan hikmah dan pelajaran yang baik dan bantahlah mereka dengan cara yang baik. Sesungguhnya Tuhanmu ialah yang lebih mengetahui tentang siapa yang tersesat dari jalan-Nya dan Dialah yang lebih mengetahui orang-orang yang mendapat petunjuk" (Q.S. Al-Nahl :125) (Departemen Agama RI, 2002: 282).

Kata al-hikmah mempunyai banyak pengertian. Dalam beberapa kamus, kata al-hikmah diartikan: al-adl (keadilan), al-hilm (kesabaran dan ketabahan), alNubuwah (kenabian), al-ilm (ilmu pengetahuan), al-Quran, falsafah, kebijakan, pemikiran atau pendapat yang baik, al-haqq (kebenaran), meletakan sesuatu pada tempatnya, kebenaran sesuatu, mengetahui sesuatu yang paling utama dengan 
ilmu yang paling utama. Dalam kitab-kitab tafsir, al-hikmah dikemukakan sebagai berikut: Tafsir Al-Quran Al-adzim karya Jalalain memberi makna bi al-hikmah dengan Al-Quran, Syekh Muhammad Nawawi Al-Jawi memberi makna bi alhikmah dengan hujjah (argumentasi), akurat, dan berpaedah untuk penetapan akidah atau keyakinan.

AlZamakhsari memberikan makna bi al-hikmah sebagai perkataan yang sudah pasti benar, yaitu dalil yang menjelaskan kebenaran dan menghilangkan keraguan atau kesamaran. Ia juga mengartikannya dengan al-Quran, yakni "serulah mereka untuk mengikuti kitab yang memuat al-hikmah". Wahbah alJuhaili dalam karyanya tafsir al-Munir memberi makna bi al-hikmah sebagai perkataan jelas dengan dalil yang terang, yang dapat mengantarkan pada kebenaran dan menyingkap keraguan.Al-Maragi memberi makna bi al-hikmah secara lebih luas, yaitu wahyu Allah yang telah diberikan kepadamu.

Dari beberapa pemaknaan al-hikmah tersebut, diambil kesimpulan bahwa dakwah bi al-hikmah pada intinya merupakan penyeruan atau pengajakan dengan cara bijak, filosofis, argumentatif, dilakukan dengan adil, penuh kesabaran dan ketabahan, sesuai dengan risalah al-nubuwwah dan ajaran al-Quran atau wahyu Illahi.

Dengan demikian terungkaplah apa yang seharusnya secara al-haq (benar) terposisikannya sesuatu secara proporsional. Menurut Ibnu Rusyd, dakwah dengan hikmah artinya dakwah dengan pendekatan substansi yang mengarah pada falsafah dengan nasihat yang baik, yang berarti retorika yang efektif dan populer, serta argumentatif atau dialektis yang unggul. Dakwah bi al-hikmah, yang berarti dakwah bijak, mempunyai makna selalu memperhatikan suasana, situasi, dan kondisi mad'u (muqtadha al-hal). Hal ini berarti menggunakan metode yang relevan dan realistis sebagaimana tantangan dan kebutuhan dengan memperhatikan kadar pemikiran dan intelektual,suasana psikologis, serta situasi sosial kultural mad'u.

Prinsip-prinsip metode dakwah bi al-hikmh ditujukan terhadap mad'u yang kapasitas intelektual pemikirannya terkategorisasikan khawas, cendikiawan, atau ilmuwan. Menurut Sayid Qutub (1997: 22), dakwah dengan metode hikmah akan terwujud apabila memperhatikan tiga faktor. Pertama, keadaan dan situasi orangorang yang didakwahi.Kedua, kadar atau ukuran materi dakwah yang disampaikan agar mereka merasa tidak keberatan dengan beban materi tersebut. Ketiga, metode penyampaian materi dakwah dengan membuat variasi sedemikian rupa yang sesuai dengan kondisi pada saat itu.

Prinsip metode ini ditujukan sebagai reaksi alternatif dalam menjawab tantangan respon negatif dari mad'u, khususnya bagi sasaran yang menolak, tidak peduli, atau bahkan melecehkan seruan. Walaupun dalam aplikasi metode ini ada watak dan suasana yang khas, yakni bersifat terbuka atau transpran, konfrontatif, dan reaksioner, juru dakwah harus tetap memegang teguh prinsip-prinsip umum dari watak dan karateristik dakwah itu sendiri; yaitu: a) Menghargai kebebasan dan hak asasi tiap-tiap individu. b) Menghindari kesulitan dan kepicikan. c) Bertahap, terprogram, dan sistematis. (Aliyudin, 2010: 1015-1020) 
Masyarakat yang dijadikan sasaran dakwah sering dianggap masyarakat yang vakum atau steril, padahal dakwah sekarang ini berhadapan dengan satu setting masyarakat dengan beragam corak dan keadaan dengan berbagai persoalannya masyarakat yang serba nilai majemuk dalam tata kehidupan, masyarakat berubah dengan cepat yang mengarah pada masyarakat fungsional, masyarakat teknologis, masyarakat saintifik, dan masyarakat terbuka.

Menurut R. Stark dan C.Y Glock dalam Robertson, (1993: 295-296), keberagamaan adalah ketaatan dan komitmen terhadap agama yang meliputi beberapa unsur diantarnya yaitu keanggotaan gereja, keyakinan kepada doktrindoktrin agama yang dianut, etika hidup kehadiran dalam acara peribadatan dan pandangan-pandangan serta lain lagi yang menunjukkan ketaatan terhadap agama. Diantara yang mendasari pengertian keagamaan menyangkut beberapa dimensi, di antaranya sebagai berikut: Pertama, dimensi keyakinan agama (ideologis), dimensi ini berisikan pengharapan-pengharapan dimana seseorang yang religius berpegang teguh teehadap pendirian teologisnya, mengakui kebenarannya atas doktrin tersebut. Salah satu perkara yang paling penting dalam keberagamaan seseorang adalah keyakinan agama yang bersifat dogmatis.Di dalam Islam keyakinan yang dimaksud adalah rukun iman.

Kedua, dimensi praktik agama, dimensi ini mencakup perilaku pemujaan, ketaatan dan hal-hal yang dilakukan oleh orang untuk menunjukkan komitmen terhadap agama yang dianutnya.Indikasi tersebut mengarah kepada pengalaman ibadah khusus, sejauh mana rutinitas seseorang dalam menjalankan ibadahnya, seperti sholat, puasa, zakat.Ketiga, dimensi pengetahuan agama, dimensi ini mengacu kepada harapan bahwa orang-orang yang beragama paling tidak memilki minimal ilmu pengetahuan mengenai dasar-dasar ritus, kitab suci dan tradisitradisi.Dimensi ini menggambarjkan sejauh mana seseorang mengetahui tentang ajaran agamanya yaitu sejauh mana aktivitasnya dalam menambah pengetahuan agamanya.Seperti apakah aktivitas keagamaannya diantaranya yaitu dengan membaca Al-Qur'an, mengikuti pengajian serta dengan membaca buku-buku yang Islami.

Keempat, dimensi penghayatan agama dimensi ini memfokuskan pada penghayatan tentang pengalaman keberagamaan seseorang, baik dari pengalaman yang diperolehnya lewat lingkungan sekitar maupun dari luar lingkungannya. Penghayatan keagamaan yang mereka dapatkan kemudian diterapkan pada kehidupan sehari-hari, apakah pengalaman keagamaannya tersebut dapat mempengaruhi proses peningkatan penghayatan keagamaannya.Kelima, dimensi pengalaman agama (konsekuensial) dimensi ini mengacu pada identifikasi akibat dari keyakinan keagamaan, praktek, pengalaman dan pengetahuan orang dari hari ke hari.Dimensi ini menjelaskan tentang sejauh mana perilaku seseorang konsekuen dengan ajaran agama yang dianutnya.

Dari beberapa uraian di atas dapat disimpulkan bahwa, perilaku keberagamaan adalah suatu keadaan diri seseorang dimana setiap melakukan atas aktivitasnya selalu bertautan dengan agamanya. Dalam hal ini pula dirinya sebagai hamba yang mempercayai Tuhannya berusaha agar dapat merealisasikan atau 
mempraktekan setiap ajaran agamanya atas dasar dimensi keberagamaan yang meliputi dimensi keyakinan agama (ideologis), dimensi praktek agama, dimensi pengetahuan agama, dimensi penghayatan agama, dimensi pengalaman agama (konsekuensial).

Tidak ada agamayang menghindari dakwah jika ia memiliki satu kesatuan intelektual. Menolak dakwah berarti menolak kebutuhan untuk mendapatkan persetujuan orang lain terhadap apa yang diklaim sebagai kebenaran agama. tidak menuntuk persetujuan, bearti tidak serius dengan klaimitu. Jelas inilah kasus ekstreme kseukuan, relativisme agama, etnosentrisme dan parokialisme. Dalam agama, seperti dalam bidang yang lain, relativisme merupakan pertahanan lemah terhadap bidang pandangan dan klaim lain. Bahkan agama-agama suku atau etnis harus meniadakan relativisme untuk menjadkan dirinya bermanfaat bahkan dikalangan penganutnya sendiri.Relativisme menunjukkan klaim "Kebenaran bagi penganunya dan klaim selain ini bisa juga benar bagi yang lain”.

Tentu saja setiap orang termasuk orang beragama, dapat mengajukan pernyataan hipotesis, dalil yang nilainya meragukan yang penerapan atau validitasnya terbatas, yang kebenarannya kabur.Namun dala agama khususnya menyangkut premis dasar keyakinan, orang yang dapat berdalih mengenai kebenaran dengan segenap kekuatan, universalisme dan keeksklusifannya.Tetapi, ketika diyakinkan tentang kebenaran dari klaim seseorang, maka orang ini harus mempertahankan klaim dari bantahan.

Perbandingan dakwah dalam perkembangan ilmu dakwah menjadi sebuah studi yang cukup menarik, terutama setelah maraknya praktik dakwah yang dilakukan umat Islam, dalam beragam cara dan pendekatan. Menariknya adalah bahwah praktik dakwah itu ada yang diterima umat Islam, ada yang gagasan dan gerakannya "dipertanyakan" dan ada pula yang ditolak umat, praktik dakwah yang tumbuh berkembang juga tidak berdiri sendiri, ia dilakukan umat Islam dengan beragam cara pendekatan, dengan mengikuti perkembang sosisal budaya dan politik global maupun global.

Pada dasarnya pola dakwah tidak jauh berbeda dengan pola komunikasi yaitu da'i-pesan-ushlub-media-mad'u. Dakwah terbagi menjadi 4 yaitu tabligh, irsyad, tathwir dan tadbir. Adapun dalam perkembangannya dakwah memiliki beberapa metode (cara) agar pesan dakwah dapat tersampaikan dengan baik, diantara lain yaitu dengan metode ceramah, metode tanya jawab, metode mujadalah, percakapan antar pribadi, metode demonstrasi metode dakwah rasul, metode pendidikan dan pengajaran, metode silaturahmi (Syukir, 1983: 104).

Dakwah dalam Islam dan misi dalam Kristen mempunyai posisi yang penting dalam upaya menyebarkan ajaran-ajaran keagamaan.Keduanya menempatkan satu dengan yang lainnya sebagai rivalitas dalam upaya mencari pengikut agama yang tak jarang menimbulkan berbagai gesekan di masyarakat yang berkaitan dengan hal-hal mencari pengikut tersebut.Sebagai agama misi (dakwah) keduanya meligitimasi bahwa ajarannya bersifat universal.

Islam di Indonesia bisa disebutkan sanat unik. Mayoritas masyarakatnya 
memeluk Islam, dengan beragam aktualisasi pemahaman dan praktik Islam meskipun mayoritas penduduk Islam tidak menjadikan Indonesia sebagai negara Islam.Nurcholis Madjid mengatakan bahwah salah satu ciri menonjol negeri Indonesi adalah keanekaragamannya, baik secara fisik maupun sosial budaya.Agama-agama besar di dunia hampir hidup di Indonesia, seperti Islam, Katolik, Protestan, Hindu dan Budha.Fakta-fakta keragaman tesebut tentu saja menyimpan berbagai kebesaran termasuk munculnya kekuasaan-kekuasaan besar seperti Sriwijaya di Palembang, Padjadjaran di Pasundan dan Majapahit di Jawa. Kekuasaan-kekuasaan yang berkembang di Indonesia tersebut jelas sangat akan berpengaruh di terhadap warna praktik Islam, apalagi Islam datang belakangan yang keudia disusul oleh Katolik dan Protestan (Aripudin dan Abdullah 2014: 31).

Sejarah Kuningan pada masa Islam tidak lepas dari pengaruh kesultanan Cirebon.Pada tahun 1470 masehi datang ke Cirebon seorang ulama besar agama Islam yaitu Syehk Syarif Hidayatullah. Syarif Hidayatullah adalah murid dari Sayid Rahmat yang lebih dikenal dengan nama Sunan Ampel yang memimpin daerah Ampeldenta di Surabaya. Masuknya agama Islam ke Kuningan nampak dari munculnya tokoh-tokoh pemimpin Kuningan yang berasal atau mempunyai latar belakang agama. Syekh Maulana Akbar, yang akhirnya menikahkan putranya bernama Syekh Maulana Arifin dengan Nyai Ratu Selawati penguasa Kuningan pada waktu itu (putri Prabu Langlangbuana). Hal ini menandai peralihan kekuasaan dari Hindu ke Islam yang berjalan dengan damai melalui Ikatan Perkawinan.Waktu itu di Kuningan muncul pendukuhan-pendukuhan yang bermula dari pembukaan-pembukaan pesantren, seperti Pesantren Sidapura (menuju Kesempurnaan), Syekh Rama Ireng (Balong Darma).Termasuk Juga di antaranya pesantren Lengkong oleh Haji Hasan Maulani.

Sebelumnya, Cigugur bernama Dusun Pandora, yang diambil dari nama Ki Gede Pandora karena beliau memiliki ilmu yang sangat dalam sehingga sangat disegani. Ketika Ki Pandora akan meninggal, ia mengucap 2 kalimat syahadat di depan Sunan Gunung Djati. Ketika Sunan Gunung Djati akan mengambil air wudu di lokasi itu sulit ditemukan setetes air, Sunan Gunung Djati kemudian memohon kepada Allah agar diturunkan air, setelah itu memancarlah air hingga menjadi kolam, setelah mengambil air wudu Ki Pandora gugur menghilang. Setelah itulah nama Cigugur tercipta $C i=$ Cai Gugur= Ilmu Pandora yang gugur karena air.

Di Kelurahan Ciggugur tidak ada yang menganut agama Katolik.Asal mula Kristenisasi di Cigugur dimulai dengan adanya sebuah kejadian di Cigugur.Ada sebuah bangunan kuno di Cigugur yang berdiri tahun 1800 bernama Paseban, dulu adalah tempatnya penganut kepercayaan Jawa-Sunda atau madrais pengikutnya sangat banyak.Dinamai Paseban karena bangunan itu merupakan tempat berkumpul merasakan keagungan Tuhan.

Pada masa Ir. Soekarno aliran kepercayaan tersebut dianggap aliran sesat dan kafir, meraka dilarang untuk melakukan segala kegiatan di penyebaran aliran kepercayaan tersebut. Para pengikutnya susah untuk menikah secara resmi karena aliran kepercaayaannya tidak diakui negara. Pada zaman kebingunan itu kemudian 
gereja Katolik masuk melancarkan proses Kristenisasi. Semenjak saat itu seluhur kepercayaan Jawa-Sunda berpindah menjadi agama Katolik dan Protestan, selain itu juga ada yang masuk ke agama Islam.Setelah banyak yang memeluk Kristen tersebut kemudian warga membangun Gua Maria Sawer Rahmat. Tapi perayaan mendekatkan diri kepada Tuhan masih sering dilakukan diberi nama Seren Taun.

Penganut kepercayaan atau Sunda Wiwitan, berawal dari Jawa Sunda yang dipimpin oleh Madrais.Pada saat dibubarkan penganut ini banyak masuk ke Katolik.Penghayat kepercayaan adalah penghayat sebagai manusia wajib untuk menghayati adanya keberadaan Tuhan Yang Maha Kuasa penghayat tidak sekedar mengakui bahwa Tuhan itu ada.Namun yang paling penting adalah penghayat menyadari bahwa mereka adalah ciptaan Yang Maha Kuasa. Di samping itu, penghayat juga bisa mengimplementasikan hablu minallah, hablu minannas dan hablu minal alam. Dalam menghayati keberadaan Tuhan Yang Maha Kuasa tidak hanya dalam upacara saja seperti menjelang matahari terbit dan terbenam penghayat berdoa. Itu hanya sekedar ritual sesaat, tapi pasca penghayat mengerjakan itu apakah penghayat bisa mengaktualisasikan doa itu dalam kehidupan sehari-hari.

Kelurahan Cigugur terkenal dengan berbagai macam agamanya.Namun Islam masih menjadi agama yang dominan.Tidak sedikit setiap tahunnya ada yang masuk Islam dan ttidak sedik ada yang keluar dari Islam juga.Biasanya orang-orang pendatang dari luar yang ingin menikah dengan pasangannya yang non-Islam.

Dari apa yang dipaparkan diatas timbul pertanyaan, pertama, bagaimana metode dakwah Islam di Kelurahan Cigugur, kedua, bagaimana metode dakwah Katolik di Kelurahan Cigugur, ketiga,bagaimana metode dakwah Penghayat di Kelurahan Cigugur, keempat, bagaimana perbandingan dakwah Islam, Katolik dan Penghayat.

Sebagai upaya mencapai tujuan penelitian, peneliti menggunakan pendekatan kualitatif dan menerapkan metode deskriptif. Dalam kajiannya, metode deskriptif menjelaskan data atau objek secara natural, objektif dan faktual (Arikunto, 1993: 310).

\section{HASIL DAN PEMBAHASAN}

Cigugur merupakan salah satu Kelurahan di Kecamatan Cigugur yang menjadi pusat dari aktivitas masyarakat. Dahulu Kelurahan Cigugur merupakan sebuah dukuh atau kampung kecil yang dihuni oleh beberapa keluarga saja. Ketika pada masa kepemimpinan kerajaan-kerajaan, Cigugur berupa dusun yang menginduk kepada daerah ramai di sebelah timur yaitu Kuningan. Pada masa itu sistem sosial Cigugur sudah termasuk kepada kemasyarakatan yang modern, dimana semakin jauh jarak sebuah daerah dari pusat kekuasaannya maka semakin otonom wilayahnya (Tendi, 2015:49).

Kemudian pada zaman kolonial Belanda, tepatnya ketika VOC menguasai wilayah Kuningan, Cigugur berada di bawah wilayah Cirebon yang terbagi kepada Cirebon Utara dan Cirebon Selatan.Wilayah Cirebon Utara meliputi daerah 
Cirebon dan Kuningan yang dipimpin oleh Sultan Sepuh, Majalengka yang dipimpin oleh Sultan Anom dan Indramayu dipimpin oleh Sultan Cirebon. Sistem tersebut bertahan hingga abad 19 hingga awal abad 20 dimana daerah Kuningan termasuk Cigugur dipimpin oleh Cirebon baik itu berupa kepresidenan ataupun kesultanan (Tendi, 2015:73).

Keanekaragaman keyakinan pada umumnya dapat diterima dengan baik oleh masyarakat Cigugur dan dapat hidup rukun saling berdampingan.Hubungan sosial antara warga yang berbeda keyakinan dapat berjalan dengan baik dan semua warga dapat menjalankan ibadahnya dengan tenang.Di kelurahan Cigugur bukanlah hal yang aneh jika dalam satu keluarga lebih dari satu keyakinan.Misalnya ibu atau bapanya menganut agama Katholik kemudian anak-anaknya menganut agama Islam atau Penghayat Kepercayaan.Perbedaan keyakinan tersebut tidak menimbulkan ketegangan diantara mereka, hubungan diantara anggota keluarga tetap terjalin dengan serasi dan masing-masing tetap menjalankan ibadahnya dengan baik.

Dalam proses kehidupan beragama, Cigugur merupakan satu wilayah yang mempunyai keragaman beragama dibandingkan dengan wilayah lain di Kabupaten Kuningan. Hal ini dibuktikan dengan berkembangnya beberapa agama di Cigugur dan satu kepercayaan yang dianut masyarakat Cigugur, yaitu agama Islam, Katholik, Protestan, Hindu, Budha, Penganut Kepercayaan dan Penghayatan Kepada Tuhan Yang Maha Esa.

Masyarakat Cigugur terbiasa untuk hidup bergotongroyong dan bekerjasama dalam berbagai bidang kehidupan.Hal ini terjadi disebabkan banyak diantara orang-orang dari beberapa kelompok penganut agama dan kepercayaan itu memiliki rasa toleransi yang tinggi untuk saling membantu dan hidup dengan kekeluargaan.Jadi, pemeliharaan rasa kebersamaan dan kedamaian seakan telah menjadi kebiasaan yang paling utama.Ajaran dan keyakinan yang terdapat dalam masing-masing kelompok tampaknya mendukung dan menjamin terlaksananya kehidupan yang mengutamakan kerukunan dan rasa toleransi.

Dari penjelasan diatas mengenai kondisi geografis dan demografis maka penulis akan menguraikan metode-metode dakwah yang dilakukan oleh kepercayaan yang ada di Kelurahan Cigugur. Hasil penelitian ini menemukan kekuatan,kelemahan, peluang dan ancaman bagi agama yang dianut oleh masyarakat di wilayah Kelurahan Cigugur.

\section{Metode Dakwah Islam di Kelurahan Cigugur Kabupaten Kuningan}

Peneliti menggunakan teori analisis swot untuk menganalisa kekuatan (strength), kelemahan (weakness), peluang (opportunities), dan ancaman (threats). Dalam hal ini peneliti mensinkronkan teori analisis SWOT dengan medan dakwah di Kelurahan Cigugur Kabupaten Kuningan dalam dakwah Islam, Katolik dan Penghayat.

Analisis SWOT adalah identifikasi berbagai factor secara sistematis untuk merumuskan strategi perusahaan. Analisis ini didasarkan pada logika yang dapat 
memaksimalkan Strengs (Kekuatan) Opportunities (Peluang) namun secara bersamaan dapat menimbulkan Weakness (Kelemahan) dan Threats (Ancaman). (Rangkuti, 2004:19)

Metode dakwah yang dilakukan oleh Islam yang dimana islam menjadi agama mayoritas di Kelurahan Cigugur terdiri dari pertama, Strength (kekuatan). Kelurahan Cigugur berada di tengah agama yang berbeda-beda, tercatat di kelurahan Cigugur ada 4.266 jiwa umat muslim. Ini menjadi kekuatan bagi masyarakat umat muslim di Kelurahan Cigugur untuk mengembangkan ajaran Islam. Dengan seiring berjalannya waktu setiap tahunnya masyarakat muslim bertambah sebagai agama pendatang di Cigugur ini perkembangan yang begitu baik sehingga setiap tahunnya terus bertambah karena pada zaman dahulu di Kelurahan Cigugur bukan agama Islam.

Karena sering ada yang yang masuk Islam, ketika ada yang baru masuk Islam ditempatkan dan diawasi oleh pengurus mushola atau masjid itu untuk menjaga mualaf itu dari keyakinan Islam agar tidak terganggu oleh hal-hal yang bisa membuat mualaf ini keluar dari Islam.

Kelurahan Cigugur dengan berbagai agama tentu menjadi daya tarik tersendiri bagi masyarakat disini, semua berlomba-lomba untuk mengajak kepada kebaikan. Islam sebagai agama mayoritas mempunyai kebiasaan yang unik karena setiap mengadakan pengajian setiap minggu ada undangan resmi ke setiap umat muslim di wilayah Kelurahan Cigugur, undangan ini bertujuan untuk menghargai masyarakat Islam sehingga memang terpanggil untuk datang, ketika diberi undangan formal melalui undangan ini akan ada rasa dihargai untuk datang ke pengajian. (Wawancara Bapak Aang, 20 Oktober 2017)

Di salah satu tempat di Kelurahan Cigugur juga ada umat muslim yang setiap dua minggu sekali mengadakan pengajian ke setiap rumah umat muslim tujuannya untuk merekatkan kembali tali silaturahmi dan melongok kondisi umat muslim yang lainnya di dalam pengajian itu terdapat da'i yang menyampaikan ceramah dan juga dibuka forum tanya jawab setelah itu dilanjutkan dengan ceritacerita rakyat disitu untuk memperkuat persaudaraan umat muslim. Kedua, Weakness (Kelemahan)

Dengan mayoritas umat muslim di Kelurahan Cigugur tentu saja perlu orangorang yang dianggap paham dan mengerti mengenai agama Islam untuk mengawal umat Islam dalam menjalankan perintah Allah SWT dan menjauhi larangannya dan menunjukkan umat muslim kepada ajaran yang benar sehingga dengan mayoritasnya umat muslim bukan sebagai angka sajamelainkan kualitas-kualitas umat muslim di sini harus diangkat kembali sebagaimana ajaran Islam.

Di Kelurahan Cigugur yang alumni pesantren/S.Ag sedikit, kebanyakan yang menjadi ustadz disini adalah orang-orang yang bukan alumni dari pesantren atau S.Ag, melainkan para sarjana atau yang dituakan. Jelas akanberbeda ketika orang yang keluaran dari pesantren atau Sarjana Agama kualitasnya dengan orang yang bukan alumni dari pesantren.Letak geografis juga mempengaruhi terhadap 
hadirnya masyarakat untuk datang ke mushola untuk menghadiri sholat berjamaah. Sehingga apa ini menjadi sedikit hambatan bagi umat muslim dikelurahan Cigugur. Ketiga, Opportunities (Peluang), untuk memperkuat umat muslim di kelurahan Cigugur dengan cara melakukan khitobah didalam pengajianpengajian. Hal tersebut dapat dimanfaatkan untuk menanamkan keyakinan, keteguhan hati dan pemahaman kepada umat muslim untuk penyadaran kekuatan umat muslim di Cigugur. Mayoritas umat muslim menjadi kekuatan tersendiri bagi Islam untuk lebih berkembang di Cigugur dan menanamkan nilai-nilai keislaman kepada seluruh umat muslim disini.

Dengan ceramah-ceramah 1 bulan sekali, 2 minggu sekali ke setiap rumah itu akan menjadi penanaman akhlaq dan pemahaman Islam kepada masyarakat Islam itu diharapkan mampu menjadi dasar dimana umat muslim menjadi kuat dan taat kepada Allah SWT.

Umat Islam diuntungkan dengan kegiatan PHBI di tempat yang terbuka karena kegiatan ini bisa disaksikan dan di dengarkan oleh orang-orang non muslim sehingga ada peluang untuk non muslim untuk masuk Islam dengan ceramah atau kegiatan yang dilaksanakan. Keempat,Threat (Ancaman) Mayoritas Umat muslim di Cigugur tentu saja menjadi kekuatan sendiri bagi Islam tetapi dibalik itu dengan mayoritasnya umat muslim ditakutkan tidak terkoordinir jangan sampai kualitas mengalahkan kuantitas. Banyaknya umat muslim di Cigugur belum seluruhnya merata pemahaman tentang Islam.

Oleh karena itu, dengan tidak memegang teguh Islam ditakutkan banyak yang melenceng dari ajaran agama Islam itu sendiri.Umat muslim pun ada yang keluar dari Islam tetapi itu bukan asli orang Cigugur kebanyakan Islam pendatang yang keluar dari Islam, ini perlu diperbaiki dikalangan umat Islam untuk mengawal Islam pendatang ke Cigugur tidak keluar dari Islam. Mencari tahu penyebab kenapa umat Islam pendatang ke Cigugur ada yang keluar dari Islam.

Lembaga MUI yang di bagian untuk mengurusi mualaf disini tidak berfungsi, seharusnya ini menjadi gerbang awal untuk mualaf sebagai Islam yang baru dalam mendalami Islam namun ketidakfungsian lembaga ini menjadi ancaman bagi umat Islam untuk mengembangkan mualaf ditakutkan keyakinannya akan tergoyahkan kembali dan proses-proses yang dilalui untuk menjadi Islam tidak resmi secara konstitusional. (Wawancara Bapak Aang, 20 Oktober 2017)

Dari hasil analisa diatas penulis menangkap beberapa hal dari metode dakwah islam yang tentunya mempunyai kekurangan dan kelebihan tersediri. Banyak yang masuk islam harus diimbangi dengan dakwah secara merata untuk menanamkan nilai-nilai keislaman sehingga orang yang sudah memeluk agama islam tidak terganggu kepercayaannya dengan kepercayaan lain yang dimana di cigugur ini sangat rentan dengan konversi agama.

Analisis ini didasarkan pada logika yang dapat memaksimalkan kekuatan (strengts) dan peluang (opportunities), namun secara bersamaan dapat meminimalkan kelemahan (weakness) dan ancaman (threats). 
Oleh karena itu perlu adanya pertimbangan-pertimbangan penting untuk analisis SWOT. (Rangkuti, 2004:18)

\section{Metode Dakwah Katolik di Kelurahan Cigugur Kabupaten Kuningan}

Kedua, peneliti menganalisa metode dakwah yang dilakukan oleh Katolik yang dimana Katolik menjadi agama mayoritas kedua di Kelurahan Cigugur. Pertama, Strength (Kekuatan), Katolik sebagai agama dengan 2.706 jiwa menjadi agama kedua setelah Islam yang masyarakatnya banyak. Setiap minggu Katolik pergi ke gereja untuk melakukan ritual ibadah, Katolik menonjolkan bagaimana mereka solid dai berbagai aspek contohnya ketika salah satu dari mereka tidak ada yang datang ke gereja untuk beribadah di hari minggu ketika ibadah selasai pastur langsung mendatangi orang yang tidak datang di waktu itu sehingga orang yang ditangi merasa diperhatikan terlepas apapun alasannya dia tidak hadir untuk beribadah di hari minggu namun langkah yang dilakukan pastur ini baik untuk memperhatikan umat kristiani yang ada hambatan untuk datang beribadah ke gereja. (Wawancara Bapak Nanda, 23 Oktober 2017)

Ketika berbeda agama ada yang mendapatkan musibah masyarakat kristiani datang untuk mendoakan yang terkena musibah tentu saja berdoa menurut kepercayaan masing-masing.Kepedulian sesama umat kristiani dan berbeda agama juga dilakukan untuk memperkuat persaudaraan umat antar beragama sehingga di kelurahan Cigugur sampai saat ini tetap rukun walaupun ada berbagai agama yang tinggal di Cigugur.

Di Katolik yang ada pendidikan terlebih dahulu kepada pastur delapan tahun untuk menyampaikan dakwah agar yang disampaikan dapat dipahami oleh pendengarnya sehingga ketika menyampaikan tidak kemana mana arahnya.

Sebelum ada simpatisan yang ingin masuk ke Katolik ada pelajaran agama terlebih dahulu dari Khalolik untuk menanamkan keyakinan kepada simpatisan itu, jadi Katolik tidak langsung membaptis orang yang ingin masuk Katolik dengan itu tidak bisa sembarangan yang masuk ke Katolik karena sebelum masuk simpatisan diberikan pelajaran terlebih dahulu untuk memahami simpatisan itu akan masuk ke Katolik. Kedua, Weakness (Kelemahan), setiap tahunnya ada saja umat kristiani yang masuk ke agama Islam. Ada beberapa faktor yang menyebabkan perpindahan agama ini, pertama melalui faktor perkawinan kedua melalui kajian tentang Islam.

Berkurangnya umat kristiani di Cigugur tentu saja menjadi kelemahan Katolik banyak yang menikah dengan orang-orang muslimsehingga memutuskan untuk pindah menjadi muslim karena untuk menikahi seorang muslim itu tentu saja berbicara perkawinan di Cigugur yang notabennya toleransi yang sangat baik namun ketika berbicara pernikahan mereka harus satu agama terlebih dahulu.

Kajian Islam ini dikarenakan kegiatan Islam lebih terbuka di tempat umum sehingga kegiatan yang di laksanakan akan terdengar oleh umat non muslim tentunya ini akan berpengaruh kepada pendengar walaupun tidak secara langsung ikut ke dalam kegiatan itu sendiri. Ketiga, Opportunities (Peluang), Katolik dengan 
sistem perkaderan yang baik tentu saja memiliki peluang-peluang untuk menambah keyakinan kepada umatnya, oleh pastur yang dididik terlebih dahulu selama delapan tahun seharusnya mampu memberikan pemahaman dan menanamkan ajaran ajaran Katolik kepada umat kristiani maka dari itu ini menjadi peluang besar untuk menjaga umat kristiani agar tidak keluar dari Katolik. Tidak mudah masuk Katolik karena ada pendidikan terlebih dahulu untuk masuk ke Katolik. Melalui proses itu seharusnya muncul orang-orang yang berkualitas karena seluruh agama mengajarkan kepada kebaikan. (Wawancara Bapak Nanda, 23 Oktober 2017)

\section{Threat (Ancaman)}

Umat kristiani di Cigugur berpotensi berkurang dikarenakan sosialisasi tentang kajian-kajian katolik tidak ditempat terbuka padahal diCigugur sangat bertoleransi dengan agama2 lain sehingga tidak menutupi kemungkinan berdakwah ditempat terbuka. Maka dari itu dengan tertutupnya penyampaian2 kepada umat kristiani itu menjadikan orang-orang tidak mengetahui yang diajarkan oleh katolik.

Berkurangnya umat katolik telah disebutkan diatas oleh dua faktor pertama perkawinan dan kajian keislaman, padahal umat kristenbetul-betul mengonsep sistem didalam pendidikan untuk menjadi misionaris begitu baik selama 8 tahun untuk menjadi misionaris atau pastur untuk menyampaikan pemahaman kepada umat katolik.

Dari hasil analisa diatas penulis menangkap beberapa hal dari metode dakwah katolik, pembinaan terhadap calon pastur sangat tersistematis sehingga ini menjadi peluang bagi Katolik untuk mengembangakan kepercayaannya namun kegiatan yang cenderung tertutup menjadi kekurangan Katolik tersendiri maka dari itu dalam menyebarkan agamanya diperlukan beberapa kegiatan yang terbuka supaya apa yang disampaikan bisa didengar oleh orang banyak terutama umatumat kristiani tidak menghadiri kegiatan-kegiatan yang ada digereja.

Analisis SWOT menurut Philip Kotler diartikan sebagai evaluasi terhadap keseluruhan kekuatan, kelemahan, peluang, dan ancaman. Analisis SWOT merupakan salah satu instrumen analisis lingkungan internal dan eksternal perusahaan yang dikenal luas. Analisis ini didasarkan pada asumsi bahwa suatu strategi yang efektif akan meminimalkan kelemahan dan ancaman. Bila diterapkan secara akurat, asumsi sederhana ini mempunyai dampak yang besar atas rancangan suatu strategi yang berhasil. (Sondang, 2000:172)

\section{Metode Dakwah Penghayat di Kelurahan Cigugur Kabupaten Kuningan}

Ketiga, peneliti menganalisa metode dakwah yang dilakukan oleh Penghayat yang dimana penganut kepercayaan minoritas di Kelurahan Cigugur. Pertama, Strength (Kekuatan) penghayat sebagai kelompok Agama Djawa Sunda yang sampai sekarang ini masih bertahan di Cigugur, mempunyai gedung pertemuan yang disebut paseban. Penghayat mengajarkan kepada penganut-penganutnya untuk 
memperkuat budi pekerti mereka karena yang ditonjolkan penghayat adalah mengenal tuhan Yang Maha Esa, manusia, dan alam. Penghayat memiliki ritual sama seperti agama-agama lain dilakukan 2 kali sehari untuk mengingat Tuhan Yang Maha Esa penghayat mengajarkan toleransi sesama manusia dan juga menjaga alam semesta.

Penghayat juga memiliki lembaga-lembaga pendidikan dari PAUD sampai SMA yang dibawah naungan Yayasan Tri Mulya sekolah itu terbuka untuk umum namun ada beberapa mata pelajaran yang disajikan khusus untuk penganut penghayat.Setiap sore ada kumpulan rutin untuk anak-anak penghayat tujuannya untuk menanamkan budi pekerti yang baik kepada anak-anak. (Wawancara Ibu Dewi Kanti, 19 November 2017).

Sesepuh adat pun sering menyampaikan petuah-petuah kepada kelompok penghayat dipaseban.Kelompok penghayat selalu mengadakan perkumpulan 2 minggu sekali di awal bulan yang bersumber dari buku Pikukuh Tilu. Kedua, Weakness (Kelemahan)

Penghayat sempat dibubarkan pada zaman dahulu tetapi masih ada orang-orang yang masih memegang kepercayaan tersebut yang sekarang paham bahwa penganut penghayat tersebar dibeberapa wilayah di Cigugur, Tasikmalaya, dan di Cimahi Bandung. Akan tetapi seluruh pusat ajaran ini berada didaerah Cigugur.

Keberadaan Penghayat yang belum diakui oleh Negara Indonesia, menyebabkan perkembangan penghayat melemah dan secara kuantitas pun semakin berkurang setiap tahunnya. Ketiga, Opportunities (Peluang) Penghayat yang mengajarkan mengenal lebih dekat dengan tuhan, manusia dan alam dapat diaplikasikan dalam kehidupan sehari-hari penghayat sangat toleran dengan seluruh agama yang ada Cigugur penghayat juga menanamkan budi pekerti yang kepada seluruh penganutnya

Karena penghayat ini tidak berdakwah untuk mengajak orang lain untuk mengikuti ajarannya namun apa yang dilakukan oleh penghayat dalam kegiatan sehari-hari mampu memberi contoh kepada penganut agama lain untuk menghayati tuhan, menghayati manusia, dan menghayati alam. Keempat, Threat (Ancaman) kepada penganut penghayat dapat dilihat dari segi politis ditakutkan ada tekanan politik dari pemerintah untuk kembali membubarkan kelompok penghayat. Di penghayat terbagi menjadi tiga golongan. Pertama,taluk adalah ketika disudutkan karena tekanan politik atau hal-hal yang lain mereka akan keluar dari penghayat dan memeluk agama lain. Kedua, tatalukan adalah ketika orang itu disudutkan karena tekanan politik atau hal-hal lain mereka keluar dari penghayat tetapi hanya sementara kemudian memeluk kembali penghayat. Ketiga,teu taluktaluk adalah umat penghayat ketika ada tekanan politik atau hal-hal lain tetap memeluk penghayat.

Dari hasil analisa diatas penulis menangkap beberapa hal dari metode dakwah penghayat, penghayat memang lebih fokus kepada pengikutnya sendiri sehingga untuk menyebarkan kepercayaannya bukanlah tujuan utama dari 
penganut kepercayaan.

Teori analisis SWOT relevan dengan keadaan di Kelurahan Cigugur yang dimana terdapat beberapa kepercayaan atau agama. Karena setiap kepercayaan mempunyai kekuatan, kelemahan, peluang dan ancaman sehinggan ini menjadi perencanaan dan strategi bagi dakwah bagi kepercayaan yang ada di wilayah Kelurahan Cigugur.

Analisis ini didasarkan pada logika yang dapat memaksimalkan kekuatan (strengts) dan peluang (opportunities), namun secara bersamaan dapat meminimalkan kelemahan (weakness) dan ancaman (threats). Oleh karena itu perlu adanya pertimbangan-pertimbangan penting untuk analisis SWOT (Rangkuti, 2004: 18).

\section{PENUTUP}

Dari penelitian yang telah dilakukan penulis mengenai analsisis metode dakwah Islam, Katolik dan Penghayat, dapat disimpulkan bahwa metode dakwah di kelurahan cigugur adalah sebagai berikut.

Islam memiliki tiga metode utama yang biasa digunakan para da'i dalam menyampaikan dakwahnya, yaitu metode bil-hikmah, manidzah hasanah, dan mujadalah. Metode bil-bikmah digunakan kepada orang-orang yang masih awam terhadap Islam dengan menyampaikan materi tentang dasar-dasar akidah dan akhlak, metode manidzah hasanah biasanya digunakan para da'i untuk menyampaikan dakwah di majelis ta'lim, pengajian rutinan, tabligh akbar, dan lainlain, sedangkan metode mujadalah digunakan saat hadir dan mengikuti forum antarumat beragama yang biasanya rutin dilaksanakan setiap satu bulan sekali. Metode dakwah dalam penyebaran Islam di Cigugur ini terbilang cukup relevan dengan keadaan mad'u di sana, misalnya dengan mengadakan pengajian keliling ke setiap rumah, karena memang jarak dari pemukiman ke tempat pengajian itu cukup memakan waktu lama. Keberhasilan tersebut dapat dilihat dari jumlah umat Islam yang menjadi mayoritas di sana, meskipun pada dasarnya Cigugur ini bukanlah kelurahan yang berakar Islam.

Metode dakwah yang digunakan dalam melakukan misi Katolik, yaitu para misionaris menggunakan pendekatan sikap solidaritas dan toleransi.Bukan hanya itu, mereka juga mengadakan pendidikan terlebih dahulu bagi calon pastur dan calon misionaris.Hal tersebut dilakukan, agar mereka lebih mudah meyakinkan umat dengan kemampuan dan pengetahuan yang dimilikinya mengenai keyakinan yang dibawanya.Di samping itu, tidak sedikit juga para Katolik yang berpindah ke agama Islam, terutama disebabkan karena adanya perkawinan.

Metode dakwah yang digunakan dalam menyebarkan ajaran penghayat tidak terlalu menonjol. Pasalnya, mereka sama sekali tidak memiliki tujuan khusus untuk mengajak orang-orang memilih keyakinannya, mereka lebi menekankan kepada penganutnya sendiri untuk menumbuhkan rasa kemanusiaan dan ketuhanan. Di sisi lain merekapun ingin menunjukkan pada semua pihak bahwa mereka itu ada dan patut dicontoh budi pekertinya. Tidak adanya pengakuan dari negara untuk agama mereka dipandang menjadi salah satu kelemahan, karena mereka tidak 
memiliki dasar yang kuat untuk tetap bertahan jika suatu saat keyakinan ini harus digusur dan dibubarkan.

Adapun perbandingan dakwah Islam, Katolik, dan Penghayat. Ketiganya memiliki cara masing-masing untuk dapat menyebarkan ajarannya. Akan tetapi, secara pola dan sistem yang dilakukan dakwah Katolik terbilang lebih unggul dibandingkan dengan Islam dan Penghayat. Hal yang paling menonjol adalah dalam pembinaan dan pendidikan da'i atau misionaris. Para misionaris dijejali pengetahuan yang lebih matang melalui pendidikan. Hal ini bertujuan agar para misionaris tidak kaku dan yakin saat menyampaikan ajarannya di depan khalayak. Berbeda dengan Islam, yang beranggapan bahwa setiap orang bisa menjadi da'i. Memang benar, tapi jika mereka tidak paham dengan apa yang disampaikan malah akan membuat perpecahan dan akhirnya perdebatan yang tidak berujung manis. Sedangkan untuk penghayat lebih memakai sistem turun temurun dan yang dituakan penganut mereka yang dijadikan simbol untuk menjalankan kepercayaan tersebut. Tidak ditemukan perbedaan yang menonjol, karena memang mereka ini sama sekali tidak memiliki tujuan untuk melakukan ajakan kepada khalayak untuk menganut ajarannya.

\section{DAFTAR PUSTAKA}

Aliyudin. (2010). Prinsip-prinsip Metode Dakwah dalam Al-Quran. Jurnal Ilmu Dakwah, 4 (15).

Alma, B. (2008). Manajemen Pemasaran dan Pemasaran Jasa. Bandung: CV. Alfabeta.

Arikunto, (1993). Prosedur Penelitian, Suatu Pendekatan Praktek. Jakarta: Rineka Cipta Edisi Kesembilan.

Aripudin, A., dkk., (2014). Perbandingan Dakwah. Bandung: Rosdakarya. AS. Enjang., Aliyudin. (2009). Dasar-dasar Ilmu Dakwah. Bandung: Widya Padjajaran.

Departemen Agama RI. (2002) Al-Quran dan Terjemahannya. Jakarta: CV Darus Sunnah.

Qonita, A. (2009). Kamus Besar Bahasa Indonesia. Bandung: PT. Indah Jaya.

Rangkuti, F. (2004)Analisis SWOT Teknik Membedah Kasus Bisnis,Jakarta: PT. Gramedia Pustaka utama.

Rokhmad, A. (2010). Ideologi dan Gerakan Dakwah Salafi Wahabi. Semarang: Rasail Media Grup.

Siagian, S. (2000) Manajemen Strategik, Jakarta : PT Bumi Aksara.

Suparta, M. (2006). Metode Dakwah. Jakarta: Kencana.

Syukir, A. (1983). Dasar-dasar Strategi Dakwah. Surabaya: Al-Ikhlas.

Tasmara, T. (1997). Komunikasi Dakwah. Jakarta: Gaya Media Pratama.

Tendi. (2015). Sejarah Agama Djawa Sunda di Cigugur Kuningan 1969-1964.

Program Magister Sejarah Peradaban Islam Fakultas Adab dan Humaniora, Jakarta: UIN Syarif Hidayatullah. 